\title{
A Comparative Study of Different Columns Sizes for Ultrafine Apatite Flotation
}

\author{
Elves Matiolo ${ }^{1, *}$, Hudson Jean Bianquini Couto ${ }^{1}$, Michelle Fernanda de Lira Teixeira ${ }^{2}$, \\ Renata Nigri de Almeida ${ }^{1}$ and Amanda Soares de Freitas ${ }^{1,3}$ \\ 1 Centro de Tecnologia Mineral (CETEM/MCTI), Rio de Janeiro 21941-908, Brazil \\ Copebras-China Molybdenum Company Ltd (CMOC International Brasil), Ouvidor (GO) 75715-000, Brazil \\ 3 Centro de Tecnologia Mineral (CETEM/MCTIC), Universidade Federal do Rio Grande do Sul (UFRGS), \\ Porto Alegre 90040-060, Brazil \\ * Correspondence: ematiolo@cetem.gov.br; Tel.: +55-21-38657334
}

Received: 19 April 2019; Accepted: 21 June 2019; Published: 28 June 2019

check for updates

\begin{abstract}
The desliming operation to discharge ultrafine particles less than $20 \mu \mathrm{m}$ prior to concentration by flotation is a common practice in phosphate ores beneficiation plants. The first industrial application for the beneficiation of the phosphate material with particle sizes $<44 \mu \mathrm{m}$ in Brazil was in the Araxá plant concentrator in the beginning of the 1980s. This work shows the comparative flotation results with two different phosphate slime samples $(<40 \mu \mathrm{m})$ obtained from the Copebras (CMOC International) industrial plant located in Catalão (Goiás state, Brazil), considering a circuit with rougher/cleaner configuration with different columns sizes, as follows: Circuit 1 (rougher-4" diameter column; cleaner-2" diameter column) and circuit 2 (rougher-6" diameter column; cleaner 4" column). The results indicate that better flotation apatite recovery results were achieved for the circuit with higher size columns (6" and 4"). The results can be explained by the application of a cavitation tube in the rougher stage in the 6 " column. The improved flotation performance can be attributed to increased probabilities of collision and attachment and the reduced probability of detachment by the small size bubbles generated by the cavitation tube in comparison with the bubbles produced by the porous tube of the 4 " column flotation.
\end{abstract}

Keywords: apatite; flotation; column flotation; slimes

\section{Introduction}

Flotation is considered the most effective technology to concentrate phosphate bearing minerals from sedimentary and igneous phosphates ores [1-3]. One of the main disadvantages of phosphate upgrading by flotation is the high sensitivity of collectors to slimes (size fraction $<44 \mu \mathrm{m}$ ). Therefore, desliming is a necessary pre-request for successful flotation [4-7] and, following this trend, the classical aim of desliming is to remove fine particles $(<37-45 \mu \mathrm{m})$ from the flotation feed. Fine/ultrafine particles account for $10-30 \%$ of losses of phosphate values in the worldwide beneficiation of phosphate ores, for instance, in Florida [8], India [9], Iran [3], Australia [6], Jordan [10], China [11], and Brazil [12-15].

There are several characterization and process studies focused on the exploitation of phosphate bearing minerals from slimes. In the case of slimes from phosphate ores from Florida, chemical and physical characterizations of slimes show that the $\mathrm{P}_{2} \mathrm{O}_{5}$ content ranges from $10 \%$ to $25 \%$ and the particle size distribution indicates that $\mathrm{d}_{80}$ are under $30 \mu \mathrm{m}$ with significant amount $(>10-30 \%)$ under $2-5 \mu \mathrm{m}$. Additionally, the mineralogical composition of the slimes indicates a high content of clay minerals, which are extremely deleterious to the flotation process [8]. Similar chemical and physical characteristics of the slimes can be found in phosphate ores from Brazil [13-15], Australia [6], and India [9]. Regarding the technological approaches to the concentration of ultrafine phosphate bearing 
minerals from slimes, one strategy is based on desliming in hydrocyclones with low diameters $(40 \mathrm{~mm})$ to remove particles under 5-10 $\mu \mathrm{m}$, followed by the flotation of the desliming product [8,13-15]. Other alternatives tested as well were flotation using a Jameson Cell [6], column flotation [3,16], and also flotation with nanobubble injection in conventional flotation machines without desliming prior to flotation [3].

Pradip and Sankar [9] carried out studies with a slime sample from the Maton rock phosphate beneficiation plant located in Rajasthan, India. One of the major sources of losses in phosphate values is due to slimes generated during the washing of the crushed ore product, called "crusher slimes". The slimes fraction $(75 \% ; 37 \mu \mathrm{m})$ consists of carbonate-fluorapatite in association with quartz, kaolinite, and limonite, and assays $18-21 \% \mathrm{P}_{2} \mathrm{O}_{5}$, accounting for $10-15 \%$ losses of phosphate values in the plant. In this work, the authors concluded that it is possible to float phosphate ore slimes, all passing $37 \mu \mathrm{m}$ (50\%; $8 \mu \mathrm{m})$, from Maton, India using a sodium oleate collector, under reagent conditions very different from what is required and currently practiced in the plant for a relatively coarser feed $(80 \% ; 74 \mu \mathrm{m})$. It should also be possible to condition the slimes separately and then combine them with the coarse ore feed in the existing flotation circuit in the plant.

In contrast with the established methods of phosphate beneficiation where classification by hydrocyclone is mainly used to remove ultrafine particles as tailings, Teague and Lollback [6] describe a process which successfully beneficiates phosphate ore with a high proportion of ultrafine particles $(80 \%<20 \mu \mathrm{m})$ to be recovered via flotation without prior classification to remove ultrafine particles $(<2-5 \mu \mathrm{m})$. The process uses conditioning with reagents at high wt \% solids (at least 70 wt $\%)$ and flotation with Jameson cells in a rougher, scavenger, cleaner configuration to recover at least $80 \% \mathrm{P}_{2} \mathrm{O}_{5}$ at a grade of $32 \% \mathrm{P}_{2} \mathrm{O}_{5}$ or greater. The Jameson cell was found to have an advantage over conventional flotation cells when treating ultrafine particles, due to their intense mixing zone and propensity to form small bubbles. Pourkarimi et al. [3] carried out studies with a slime sample from the Esfordi phosphate processing plant from the central desert in Iran in Yazd province. The ore contained about $10 \%$ of the mass, with a grade of more than $16 \% \mathrm{P}_{2} \mathrm{O}_{5}$ and $d_{80}$ of less than $30 \mu \mathrm{m}$. The authors compared the results considering flotation in the presence and absence of nanobubbles using a Denver flotation cell and carried out the generation of nanobubbles based on the cavitation phenomenon through a venturi tube. The flotation results indicated that the existence of nanobubbles in the process had positive effects, so that more than $90 \%$ of phosphates with a grade of more than $40 \%$ were recoverable in the presence of nanobubbles, while in their absence, under the same conditions, the $\mathrm{P}_{2} \mathrm{O}_{5}$ grade was $37 \%$. The recovery of apatite in flotation in the presence of nanobubbles significantly increased up to more than $30 \%$, compared to flotation in the absence of nanobubbles.

One alternative to the flotation of phosphate slimes is the application of the column flotation [10,12-16]. Al-Thyabat et al. [7] evaluated the floatability of Jordanian phosphate slime $(<38 \mu \mathrm{m})$ in a batch column flotation cell, $100 \mathrm{~cm}$ high and $5 \mathrm{~cm}$ in diameter. Flotation was conducted using sodium oleate as a collector and methyl isobutyl carbinol (MIBC) as a frother. Rougher flotation yielded a concentrate assaying $29.19 \% \mathrm{P}_{2} \mathrm{O}_{5}$ with $90.29 \%$ recovery at the following flotation parameters: A total $2.6 \mathrm{~cm} / \mathrm{s}$ superficial gas velocity, $20 \mathrm{ppm}$ frother dosage, $0.205 \mathrm{mmol} / \mathrm{L}$ collector concentration, and $40 \%$ weight solids. It was also found that conditioning with the same collector dosage, but with a different solids weight percent, gave different flotation results.

The Brazilian phosphate industry has made great efforts to develop technology for the production of phosphates from slimes as shown by Guimarães and Peres [12-14]. The first industrial application was in the Araxá concentrator in the beginning of the 1980s, in a circuit consisting of desliming in $40 \mathrm{~mm}$ hydrocyclones and apatite flotation in column machines. This technology has been upgraded since 1984 by means of significant improvements in the desliming operation, concerning equipment and process control, utilization of a more adequate reagent system, and the use of flotation machines that provide improved performance and metallurgical yield. The concept of this process was still expanded to other Brazilian plants located in Catalão (Goiás state), Tapira (Minas Gerais state), and Cajati (São Paulo state) in the 1990s. It is estimated that the apatite concentrate from slimes represents 
$11 \%$ to $13 \%$ of the overall production. The apatite concentrate grade achieved from slimes are $\mathrm{P}_{2} \mathrm{O}_{5}$ at 33.0-35\%; $\mathrm{Fe}_{2} \mathrm{O}_{3}$ at 3.0-6.5\%; $\mathrm{Al}_{2} \mathrm{O}_{3}$ at $0.4-1.0 \% ; \mathrm{MgO}$ at $0.1-1.6 \%$, and $\mathrm{SiO}_{2}$ at $1.5-5.5 \%$. More recently, Matiolo et al. [15] showed the results of a flowsheet developed for apatite concentration from a slime sample provided by the industrial phosphate ore plant Copebras (China Molybdenum-CMOC International), located in Catalão (Goiás state, Brazil). Considering the flowsheet with the desliming in the hydrocyclones (40 $\mathrm{mm}$ in diameter) in two stages, followed by apatite flotation in the column, a final concentrate of $35.6 \% \mathrm{P}_{2} \mathrm{O}_{5}$ was obtained, with main impurities of $\mathrm{Fe}_{2} \mathrm{O}_{3}$ and $\mathrm{SiO}_{2}$ around $4.0 \%$ and $5.1 \%$, respectively, using only rougher flotation. Taking into account the mass and metallurgical balances of desliming and flotation, the overall mass recovery was around $9.5 \%$ and the $\mathrm{P}_{2} \mathrm{O}_{5}$ recovery was $25.5 \%$.

This work is the continuation of previous work with the Copebras phosphate slime samples. by Matiolo et al [15] This article does a comparison considering a circuit with rougher/cleaner configuration with different sized columns flotations, as follows: Circuit 1 (ro-ugher4" diameter column; cleaner-2" diameter column), and circuit 2 (rougher-6" diameter column; cleaner 4" column). The influence of collector and depressant dosages, pulp $\mathrm{pH}$, superficial wash water velocity (Jw), ore variability, and superficial air velocity $(\mathrm{Jg})$ were evaluated on the flotation separation parameters $\left(\mathrm{P}_{2} \mathrm{O}_{5}\right.$ grade and recovery and impurities content) for both circuits. The chemical quality target for the apatite concentrate is $\mathrm{P}_{2} \mathrm{O}_{5}>33.0 \%, \mathrm{SiO}_{2}<8 \%$, and $\mathrm{Fe}_{2} \mathrm{O}_{3}<6.5 \%$.

\section{Experimental}

\subsection{Ore Sample}

The two slime samples tested in this work were provided by Copebras (CMOC International) located in Catalão (Goiás state), Brazil. Detailed information on the sample preparation procedures can be found in the study by Matiolo et al. [15]. The slime samples were collected from the overflow of the hydrocyclones, which was around 10 tons (dry basis) of the slime in pulp with 16\% solid content by weight. The sample characterization included chemical analyses by X-ray fluorescence (PANalytical AXIOS WDS, PANalytical, Almero, the Netherlands) and mineralogical characterization by XDR (Rietveld method) (Bruker-D4 Endeavor, Bruker, Germany). The particle size distribution was determined by the laser diffraction technique using a Malvern Master size particle analyzer (Malvern Panalytical Ltd., Malvern, UK).

The particle size distribution of slime Sample 1 showed that the characteristics for diameters $D_{32}$, $D_{10}, D_{50}$, and $D_{90}$ were, respectively, $2.6 \mu \mathrm{m}, 1.0 \mu \mathrm{m}, 5.7 \mu \mathrm{m}$, and $24.7 \mu \mathrm{m}$, whereas for Sample 2 the values were $D_{32}=5.0 \mu \mathrm{m}, D_{10}=2.1 \mu \mathrm{m}, D_{50}=13.8 \mu \mathrm{m}$, and $D_{90}=43 \mu \mathrm{m}$. The chemical analyses for both samples showed that the $\mathrm{P}_{2} \mathrm{O}_{5}$ grade was around 12-13\% and the $\mathrm{CaO}$ was around 11-14\%. In terms of the major contaminants, $\mathrm{SiO}_{2}$ and $\mathrm{Fe}_{2} \mathrm{O}_{3}$ stood out, with grades of $19.7 \%$ and $27.7 \%$ for Sample 1 and $15.8 \%$ and $24.8 \%$ for Sample 2, respectively (Table 1 ). The main mineral phases in the samples were apatite (around 33\%), goethite with a $26 \%$ grade content, and quartz with $18 \%$.

Table 1. Chemical analysis of the slime samples.

\begin{tabular}{cccccccccc}
\hline Sample & $\mathrm{Al}_{2} \mathbf{O}_{3}$ & $\mathrm{BaO}$ & $\mathrm{CaO}$ & $\mathrm{Fe}_{\mathbf{2}} \mathbf{O}_{3}$ & $\mathbf{M g O}$ & $\mathbf{P}_{\mathbf{2}} \mathrm{O}_{5}$ & $\mathrm{SiO}_{2}$ & $\mathbf{N b}_{2} \mathbf{O}_{5}$ & $\mathbf{C a O} / \mathbf{P}_{2} \mathbf{O}_{5}$ \\
\hline 1 & 3.9 & 1.2 & 14.0 & 27.7 & 2.4 & 13.3 & 19.7 & 0.62 & 1.05 \\
\hline 2 & 2.8 & 1.6 & 16.5 & 30.0 & 1.0 & 14.0 & 12.5 & 0.89 & 1.18 \\
\hline
\end{tabular}

\subsection{Desliming}

Figure 1 shows the apparatus for the desliming operation of the slime samples. Each container, holding $1 \mathrm{~m}^{3}$ (40 in total) of the slime sample, was connected to a vertical pump with a system that allowed pulp recirculation to the container and also to a $3.6 \mathrm{~m}^{3}$ tank. In this tank, water was added to adjust the solids in the pulp to around 8\%, which represented the solids to the feed of the desliming 
stage. From the storage tank, the pulp was pumped to the hydrocyclone apparatus. Desliming was carried out in two stages, where the underflow from the first stage fed the second stage. The underflow of the second stage fed the apatite flotation and the overflow from both stages was discharged as tailings. The hydrocyclone used was supplied by Weir Minerals. The apex finder was $7 \mathrm{~mm}$ in the first stage and $5.5 \mathrm{~mm}$ in the second. In both stages, the vortex finder was $10 \mathrm{~mm}$ and the operational pressure was $4 \mathrm{kgf} / \mathrm{cm}^{2}$ in the first stage and $3 \mathrm{kgf} / \mathrm{cm}^{2}$ in the second.
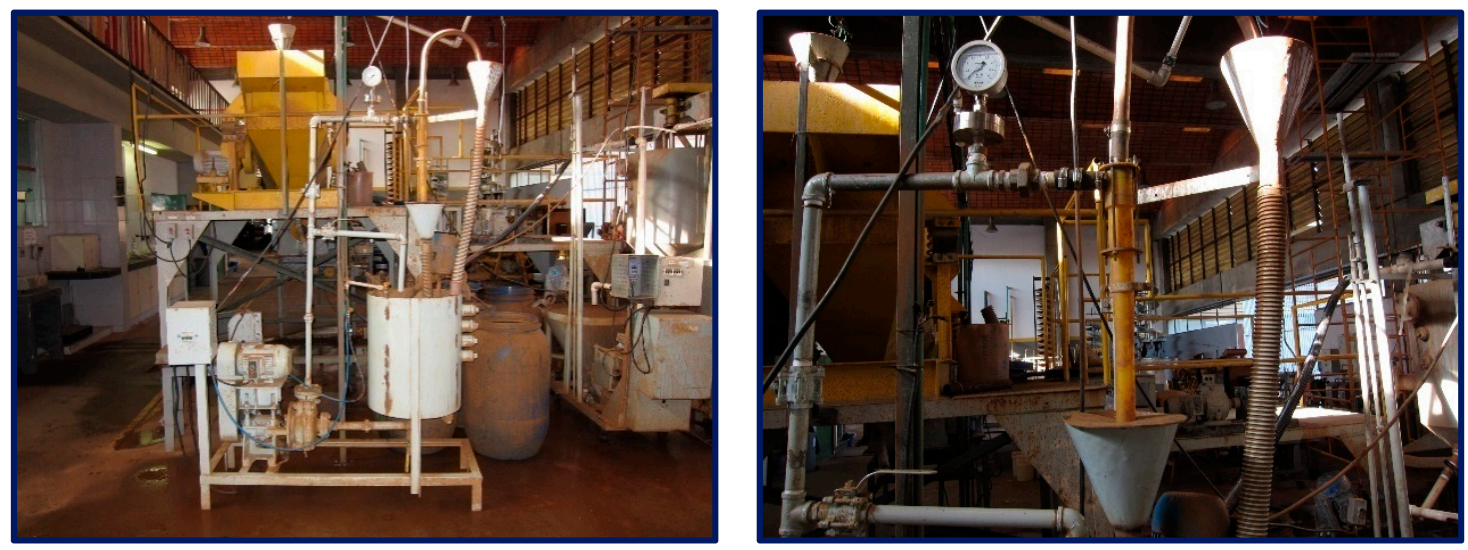

Figure 1. Apparatus for the desliming operation.

\section{Flotation Studies}

\subsection{Reagents}

Soybean oil soap was used as an apatite collector and was obtained after saponification for a period of $15 \mathrm{~min}$ with a fatty acid/ $\mathrm{NaOH}$ ratio of 5:1. Gelatinized corn starch was used as the gangue mineral depressant, with a starch/ $\mathrm{NaOH}$ ratio of $4: 1$ and a reaction time of $10 \mathrm{~min}$, in a solution with concentration at $20 \% w / w$. After the saponification and gelatinization, both reagents were diluted in distilled water, producing $1 \% w / w$ solutions. For $\mathrm{pH}$ adjustment, a $2 \% \mathrm{NaOH}$ solution was used. Tap water from the city of Rio de Janeiro's supply network was used to attain the correct percentage of pulp solids in the flotation studies.

\subsection{Pilot Plant Flotation Tests}

Figure 2a shows the schematic flowsheet considering the desliming and flotation stages for apatite concentration from the slime samples and Figure $2 b$ shows a general view of the columns at CETEM's pilot plant (ERIEZ, Delta, Canada). The underflow obtained in the second stage of desliming, at 35\% solid content by weight, fed the flotation circuit. The rougher/cleaner flotation trials were performed using columns with internal diameters of $6^{\prime \prime}, 4^{\prime \prime}$, and $2^{\prime \prime}$ and a height of $7.0 \mathrm{~m}$. The effective volume of each column was $100 \mathrm{~L}, 46 \mathrm{~L}$, and $13 \mathrm{~L}$, respectively. The main objective of this study was to compare the flotation performance considering a rougher/cleaner circuit for apatite flotation with the following two different circuits: Circuit 1 (rougher-4" diameter column; cleaner-2" diameter column) and circuit 2 (rougher-6" diameter column; cleaner 4" column). The solid feed rate in each circuit was $35 \mathrm{~kg} / \mathrm{h}$ and $46 \mathrm{~kg} / \mathrm{h}$ dry basis, respectively.

From the storage tank, the pulp was pumped to a cylindrical tank where it was conditioned with gelatinized corn starch and the $\mathrm{pH}$ was adjusted (between 9.5 and 10.8) with $\mathrm{NaOH}$. The depressant dosage ranged from $2300 \mathrm{~g} / \mathrm{t}$ up to $3000 \mathrm{~g} / \mathrm{t}$. After conditioning with the depressant, the pulp was conditioned with soybean oil soap in a cylindrical tank, at 35\% solids by weight, with dosages from $70 \mathrm{~g} / \mathrm{t}$ to $130 \mathrm{~g} / \mathrm{t}$. The mean residence time for conditioning was $10 \mathrm{~min}$ for the depressant and around $20 \mathrm{~min}$ for the collector. After conditioning, the pulp was diluted to $20 \%$ solids by weight and fed in the rougher column. The froth obtained in the rougher fed the cleaner, and the sink fractions from rougher and cleaner were discharged as final tailings. Bubbles were generated with controlled pressure and 
flow via a forced air passage in a porous tube at the bottom of the 4 " and 2" columns. The bubble generation of the 6 " column flotation was through the recirculation of a portion of the pulp through a cavitation tube. The operational pressure on the cavitation was around $3.5 \mathrm{kgf} / \mathrm{cm}^{2}$. The pulp/froth interface was controlled by a level sensor that was connected to the tailings pump and the wash water and air flow rate were controlled by a flow meter. After reaching the stationary stage, samples of the rougher and cleaner tailings and cleaner concentrate were collected simultaneously for 2 min for mass and metallurgical balances. The samples were flocculated and dried in an oven for $24 \mathrm{~h}$ at $80^{\circ} \mathrm{C}$. Then, the samples were weighed, disaggregated, and separated in aliquots for chemical analysis by $\mathrm{X}$-ray fluorescence spectroscopy to determine the metallurgical balance.

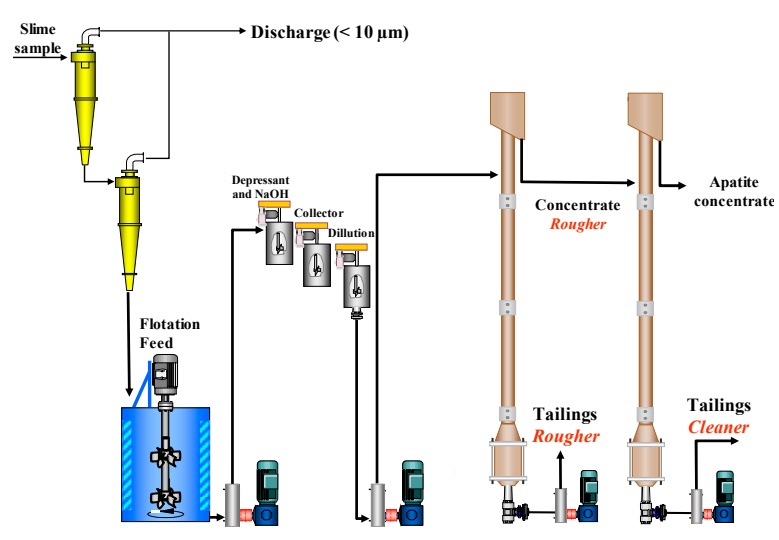

(a)

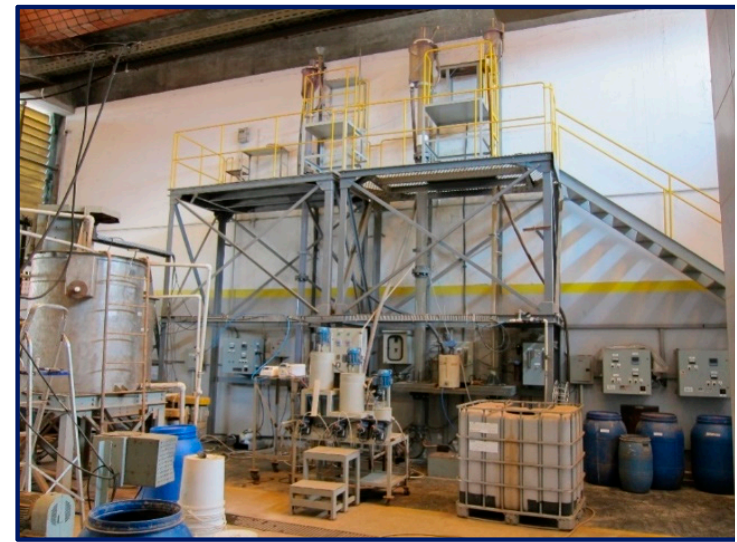

(b)

Figure 2. Schematic flowsheet for the apatite concentration from (a) the slime samples and photo from (b) the column flotation units.

\section{Results and Discussion}

\subsection{Desliming}

The mass and oxide balance for the optimized desliming conditions for Sample 1 are shown in Table 2. The feed of the first desliming stage contained $8 \%$ solids by weight and produced an underflow with $16 \%$ solids by weight and an overflow with $2-3 \%$ solids by weight, which was discharged as final tailings. The mass and $\mathrm{P}_{2} \mathrm{O}_{5}$ recoveries of the underflow were $70 \%$ and $78 \%$, respectively. The $\mathrm{P}_{2} \mathrm{O}_{5}$ grade increased from $13.3 \%$ at the feed to $14.3 \%$ in the underflow. The $\mathrm{P}_{2} \mathrm{O}_{5}$ in the overflow was $10.1 \%$. The underflow of the first stage fed the second stage, which was carried out in the same hydrocyclone applied in the first stage with an apex finder of $5.5 \mathrm{~mm}$ and the operation pressure was regulated to $3 \mathrm{kgf} / \mathrm{cm}^{2}$. The solids content in the overflow of the second stage was $4-5 \%$, the $d_{50}$ was $5 \mu \mathrm{m}$, and the $\mathrm{P}_{2} \mathrm{O}_{5}$ grade was $11 \%$ and was discharged with the final tailings together with the overflow produced at the first stage. The solids content in the underflow of the second stage was 35-36\%, the $\mathrm{d}_{50}$ was $18 \mu \mathrm{m}$, and the $\mathrm{P}_{2} \mathrm{O}_{5}$ grade was $16.4 \%$. The mass and $\mathrm{P}_{2} \mathrm{O}_{5}$ recoveries at the second stage were very similar to the first stage, reaching $70 \%$ and $77 \%$. The underflow obtained at the second stage fed the conditioning circuit and then the flotation circuit. Considering both stages, the overall mass recovery was around $50 \%$ and the $\mathrm{P}_{2} \mathrm{O}_{5}$ recovery was $60 \%$. Regarding the $\mathrm{SiO}_{2}$ and $\mathrm{Fe}_{2} \mathrm{O}_{3}$ contaminants, it was observed that the iron impurities tended to decrease after desliming, as opposed to what was observed for the $\mathrm{SiO}_{2}$ content, which tended to increase after this process.

The results of the desliming stage for Sample 2 are shown in Table 3. The $\mathrm{P}_{2} \mathrm{O}_{5}$ content at the flotation feed (underflow of second stage) was quite similar to that obtained for Sample 1, assaying around $16 \%$. Regarding the $\mathrm{SiO}_{2}$ and $\mathrm{Fe}_{2} \mathrm{O}_{3}$ impurities, a reduction of the iron bearing minerals content in the flotation feed was observed when compared to the feed sample, as observed in Sample 1. The $\mathrm{SiO}_{2}$ content in the flotation feed was almost the same as that in the feed process sample. 
Table 2. Metallurgical and mass balance of the desliming stage (Sample 1).

\begin{tabular}{|c|c|c|c|c|c|c|c|c|c|c|c|c|c|c|}
\hline \multirow{2}{*}{ Stage } & \multirow{2}{*}{ Stream } & \multirow{2}{*}{$\begin{array}{c}\text { Mass } \\
\text { Rec (\%) }\end{array}$} & \multicolumn{6}{|c|}{ Grade (\%) } & \multicolumn{6}{|c|}{ Distribution (\%) } \\
\hline & & & $\mathrm{Al}_{2} \mathrm{O}_{3}$ & $\mathrm{CaO}$ & $\mathrm{Fe}_{2} \mathrm{O}_{3}$ & $\mathrm{MgO}$ & $\mathrm{P}_{2} \mathrm{O}_{5}$ & $\mathrm{SiO}_{2}$ & $\mathrm{Al}_{2} \mathrm{O}_{3}$ & $\mathrm{CaO}$ & $\mathrm{Fe}_{2} \mathrm{O}_{3}$ & $\mathrm{MgO}$ & $\mathrm{P}_{2} \mathrm{O}_{5}$ & $\mathrm{SiO}_{2}$ \\
\hline \multirow[b]{2}{*}{1} & Over & 29.9 & 4.5 & 9.9 & 33.9 & 2.3 & 10.1 & 16.5 & 35.4 & 21.4 & 36.9 & 29.0 & 23.1 & 25.3 \\
\hline & Under & 70.1 & 3.5 & 15.5 & 24.7 & 2.4 & 14.3 & 20.7 & 64.5 & 78.5 & 63.0 & 70.9 & 76.8 & 74.6 \\
\hline \multirow[b]{2}{*}{2} & Over & 29.8 & 4.4 & 11.5 & 31.1 & 2.5 & 11.3 & 17.3 & 37.5 & 21.3 & 40.0 & 31.5 & 22.5 & 24.0 \\
\hline & Under & 70.2 & 3.1 & 17.9 & 19.7 & 2.3 & 16.4 & 23.2 & 62.4 & 78.6 & 59.9 & 68.4 & 77.4 & 76.0 \\
\hline \multicolumn{2}{|c|}{ Feed } & 100 & 3.8 & 13.8 & 27.4 & 2.4 & 13.0 & 19.4 & 100 & 100 & 100 & 100 & 100 & 100 \\
\hline
\end{tabular}

Table 3. Metallurgical and mass balance of the desliming stage (Sample 2).

\begin{tabular}{|c|c|c|c|c|c|c|c|c|c|c|c|c|c|c|}
\hline \multirow{2}{*}{ Stage } & \multirow{2}{*}{ Stream } & \multirow{2}{*}{$\begin{array}{c}\text { Mass } \\
\operatorname{Rec}(\%)\end{array}$} & \multicolumn{6}{|c|}{ Grade (\%) } & \multicolumn{6}{|c|}{ Distribution (\%) } \\
\hline & & & $\mathrm{Al}_{2} \mathrm{O}_{3}$ & $\mathrm{CaO}$ & $\mathrm{Fe}_{2} \mathrm{O}_{3}$ & $\mathrm{MgO}$ & $\mathrm{P}_{2} \mathrm{O}_{5}$ & $\mathrm{SiO}_{2}$ & $\mathrm{Al}_{2} \mathrm{O}_{3}$ & $\mathrm{CaO}$ & $\mathrm{Fe}_{2} \mathrm{O}_{3}$ & $\mathrm{MgO}$ & $\mathrm{P}_{2} \mathrm{O}_{5}$ & $\mathrm{SiO}_{2}$ \\
\hline \multirow{2}{*}{1} & Over & 43.2 & 3.7 & 12.9 & 35.3 & 1.2 & 11.5 & 12.3 & 58.4 & 33.9 & 51.4 & 43.1 & 34.8 & 42.6 \\
\hline & Under & 56.8 & 2.0 & 19.2 & 25.5 & 1.2 & 16.4 & 12.6 & 41.6 & 66.1 & 48.6 & 56.9 & 65.2 & 57.4 \\
\hline \multirow{2}{*}{2} & Over & 15.0 & 2.8 & 10.9 & 28.8 & 1.1 & 12.7 & 10.5 & 20.3 & 8.9 & 17.9 & 13.5 & 11.7 & 12.0 \\
\hline & Under & 85.0 & 1.9 & 19.8 & 23.4 & 1.2 & 16.9 & 13.3 & 79.7 & 91.1 & 82.1 & 86.5 & 88.3 & 88.0 \\
\hline \multicolumn{2}{|c|}{ Feed } & 100 & 2.7 & 16.5 & 29.7 & 1.2 & 14.3 & 12.5 & 100 & 100 & 100 & 100 & 100 & 100 \\
\hline
\end{tabular}

\subsection{Flotation Studies}

This topic presents the results and discussion of the apatite flotation studies considering rougher/cleaner flotation in 6", 4", and 2" columns. As mentioned before, one circuit consisted of the application of a $6 "$ column for the rougher stage and a 4 " column for the cleaner. The second circuit applied the 4" column for rougher flotation and a 2" column for the cleaner. The influence of collector and depressant dosages, wash water superficial velocity, $\mathrm{pH}$, and air superficial velocity were evaluated on flotation separation parameters. The flotation recovery was calculated as a function of the hydrocyclone underflow (flotation feed).

Figure 3 shows the curve of the $\mathrm{P}_{2} \mathrm{O}_{5}$ grade versus the recovery, considering apatite rougher/cleaner configuration for both circuits evaluated. As shown in the figure, the $\mathrm{P}_{2} \mathrm{O}_{5}$ recovery ranged from $80 \%$ to $25 \%$ with a $\mathrm{P}_{2} \mathrm{O}_{5}$ grade variation from $22 \%$ to almost $38 \%$. In general terms, the flotation performance (grade and recovery) in the circuit with 6" and 4" columns was better compared to the circuit with $4^{\prime \prime}$ and 2" columns, especially for the $\mathrm{P}_{2} \mathrm{O}_{5}$ grade between $30 \%$ and $34 \%$.

Figure 4a shows the comparative results for the $\mathrm{P}_{2} \mathrm{O}_{5}$ grade/recovery curve considering the rougher flotation in the 6 " and 4 " columns and for cleaner flotation considering the 4 " and 2" columns (Figure 4b). The results for the circuit applied in the 6" and 4" columns were obtained with the flotation of Samples 1 and 2 and considering the Sample 1 flotation for the circuit with the 4" and 2" diameter columns. The performance (grade and recovery) of rougher flotation in the 6 " diameter column was superior to the results obtained for the 4" diameter column. As it can be observed, the $\mathrm{P}_{2} \mathrm{O}_{5}$ recovery ranged from $90 \%$ to $40 \%$, with a $\mathrm{P}_{2} \mathrm{O}_{5}$ grade variation from $17 \%$ to almost $34 \%$. Furthermore, a linear relation between the $\mathrm{P}_{2} \mathrm{O}_{5}$ grade and losses was verified for the rougher tailings.

A fundamental difference between both columns is the fact that the bubble generator of the 6 " column is a cavitation tube, while the bubble generator of the 4 " column is a porous tube. Hydrodynamic cavitation to generate bubbles has been use to enhanced the flotation of fine and ultrafine particles [17-19]. Tao et al. [17] evaluated the effect of picobubble injection produced by the hydrodynamic cavitation principle in association with the conventional sized bubbles produced by a static mixer on the flotation response of fine coal particles. The results indicated that picobubbles significantly enhanced the coal flotation process with higher recovery and lower product ash. The flotation recovery increased by $10-30 \%$ depending on the process operating conditions. Zhou et al. [18] incorporated a cavitation tube in the feed line to a conventional flotation cell for the flotation of fine silica and $\mathrm{ZnS}$ precipitates $(<5 \mu \mathrm{m})$. The results showed that there is a substantial increase in fine silica recovery for a given flotation period when using the cavitation tube (without 
added air). Additionally, a 40\% increase in rate constant was obtained using a cavitation tube (1.3 mm nozzle diameter), even though the overall aeration was less $(2.15 \mathrm{~L} / \mathrm{min}$ compared to $3 \mathrm{~L} / \mathrm{min}$ without the tube). This increase in the flotation rate constant again suggests that small bubbles generated by cavitation in the feed stream played a role in enhancing flotation kinetics.

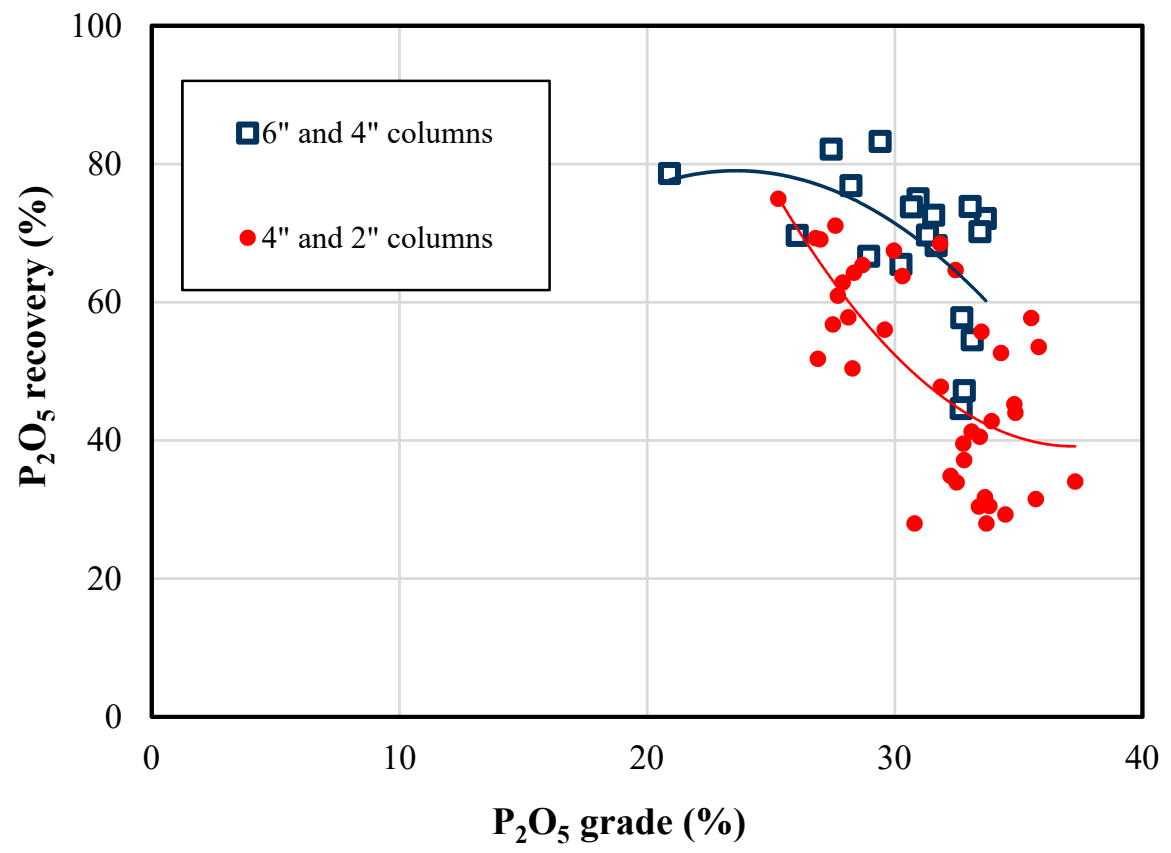

Figure 3. P2O5 grade/recovery curves for rougher/cleaner flotation. Comparative results of the circuit with 6" and 4" and 4" and 2" column flotation.

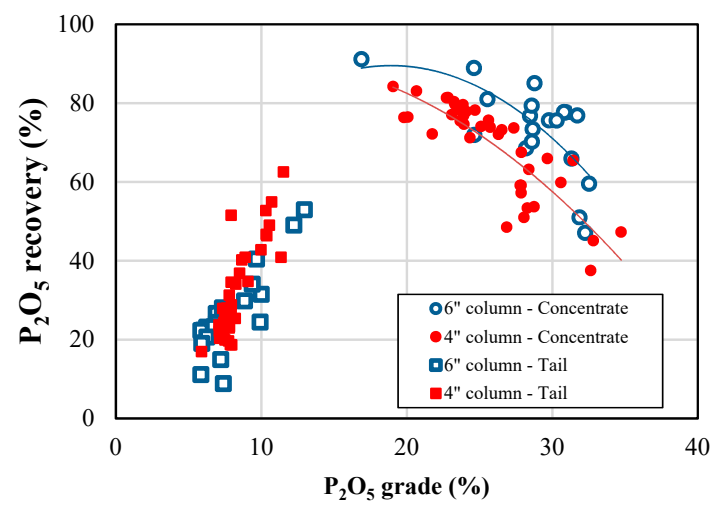

(a) Rougher flotation

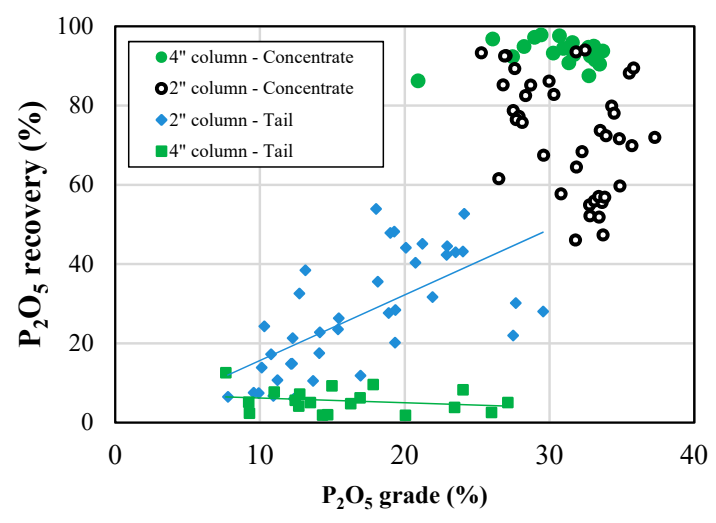

(b) Cleaner flotation

Figure 4. P2O5 grade/recovery curves for rougher (a) and cleaner (b) stages. Comparative results for rougher flotation in 6" and 4" column flotation and for cleaner flotation in 4" and 2" column flotation.

As for cleaner flotation, it could be observed that the results obtained in the flotation with the 2" column showed a higher distribution compared to the results obtained for the 4" column. This can be explained by the fact that cleaner flotation in the 2 " column had more process variables tested, focused on optimization of this stage, including changes in the superficial air velocity (Jg) and wash water (Jw), besides the reagents dosage variation. For the flotation in the 4 " column as a cleaner, only the effect of the collector, depressant dosage, and $\mathrm{pH}$ were evaluated for $\mathrm{Jg}$ and the Jw kept fixed at $0.51 \mathrm{~cm} / \mathrm{s}$ and $0.20 \mathrm{~cm} / \mathrm{s}$, respectively. The $\mathrm{P}_{2} \mathrm{O}_{5}$ losses on the cleaner flotation with the 4 " column ranged from $2 \%$ to a maximum of $12 \%$, considering the $\mathrm{P}_{2} \mathrm{O}_{5}$ grade variation from $9 \%$ to $25 \%$. On the other hand, it could be observed that the cleaner flotation in the 2 " column showed a much higher variation, especially 
for the $\mathrm{P}_{2} \mathrm{O}_{5}$ losses, which ranged from $10 \%$ to values up to $24 \%$ for the similar $\mathrm{P}_{2} \mathrm{O}_{5}$ content in the sink fraction.

The relation between the $\mathrm{P}_{2} \mathrm{O}_{5}$ grade in the final apatite concentrate and the content of $\mathrm{Fe}_{2} \mathrm{O}_{3}$ and $\mathrm{SiO}_{2}$ impurities for both circuits evaluated are shown in Figure 5. The variation of the $\mathrm{Fe}_{2} \mathrm{O}_{3}$ content in the final apatite concentrate is very similar for both circuits and it is independent of the sample. The $\mathrm{SiO}_{2}$ content has the same trend observed for the iron impurities in Sample 1 for both circuits, whereas the $\mathrm{SiO}_{2}$ content in the final concentration of Sample 2 is significantly lower than that obtained for Sample 1. These results indicate that contamination of the apatite concentrate strongly depends on the ore characteristics that feed the plant and it is less influenced by the scale tested. As shown before, the $\mathrm{SiO}_{2}$ grade in Sample 2 is much lower when compared with Sample 1, unlike the iron content, which is quite similar in both samples.

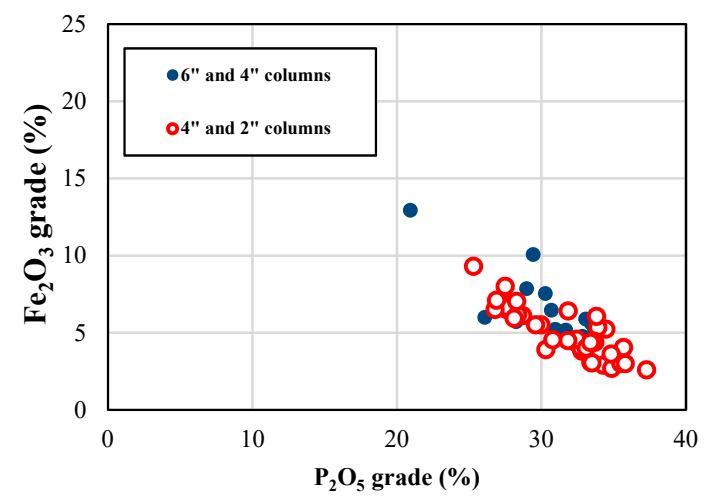

(a) $\mathrm{Fe}_{2} \mathrm{O}_{3}$ content-Cleaner concentrate

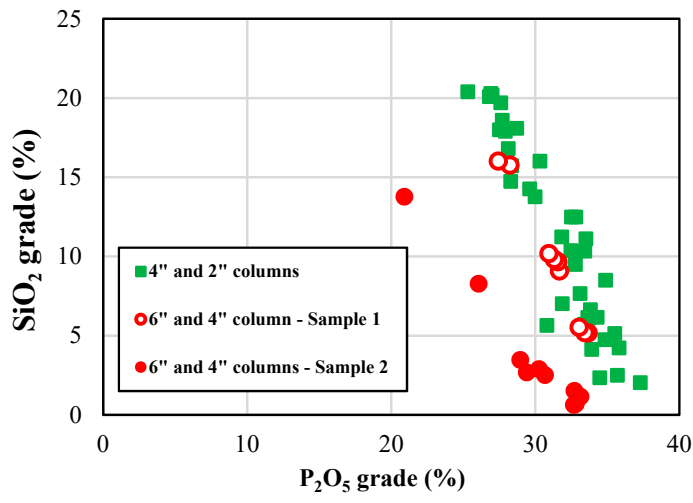

(b) $\mathrm{SiO}_{2}$ content-Cleaner concentrate

Figure 5. Relation between the $\mathrm{P}_{2} \mathrm{O}_{5}$ grade and $\mathrm{Fe}_{2} \mathrm{O}_{3}(\mathbf{a})$ and $\mathrm{SiO}_{2}(\mathbf{b})$ impurities in the final apatite concentrate for both circuits. Flotation studies with Samples 1 and 2.

A summary of the best results achieved using rougher/cleaner configuration for the circuit with the 4" and 2" columns is shown in Table 4 for the flotation studies with Sample 1. Considering the average results for the three tests, mass recovery was around $23 \%$ and $\mathrm{P}_{2} \mathrm{O}_{5}$ recovery and grade were $54 \%$ and $35.2 \%$, respectively. The $\mathrm{SiO}_{2}$ and $\mathrm{Fe}_{2} \mathrm{O}_{3}$ impurities levels were $3.0 \%$ and $5.2 \%$. Reagent consumptions were $117 \mathrm{~g} / \mathrm{t}$ to the collector, around $2700 \mathrm{~g} / \mathrm{t}$ to the depressant, and $410 \mathrm{~g} / \mathrm{t}$ to $\mathrm{NaOH}$ and the pulp $\mathrm{pH}$ was fixed at 9.7.

Table 4. Summary of the best results obtained in experiments at 4 " and 2" column flotation. Rougher/cleaner. Feed solids rate: $35 \mathrm{~kg} / \mathrm{h} ; \mathrm{pH}=$ 9.7. Flotation studies with Sample 1.

\begin{tabular}{cccccccc}
\hline \multirow{2}{*}{ Test } & \multicolumn{2}{c}{ Recovery (\%) } & \multicolumn{3}{c}{ Grade (\%) } & \multicolumn{2}{c}{ Consumption $\mathbf{( g / t )}$} \\
\cline { 2 - 7 } & Mass & $\mathbf{P}_{\mathbf{2}} \mathbf{O}_{\mathbf{5}}$ & $\mathbf{P}_{\mathbf{2}} \mathbf{O}_{\mathbf{5}}$ & $\mathbf{F e}_{\mathbf{2}} \mathbf{O}_{\mathbf{3}}$ & $\mathbf{S i O}_{\mathbf{2}}$ & Collector & Depressant \\
\hline 1 & 24.2 & 52.7 & 34.3 & 2.9 & 6.2 & 123 & 2353 \\
2 & 25.3 & 57.7 & 35.5 & 3.0 & 5.1 & 116 & 2737 \\
3 & 22.7 & 53.5 & 35.8 & 3.0 & 4.2 & 113 & 3259 \\
Average & 24.1 & 54.6 & 35.2 & 3.0 & 5.2 & 117 & 2783 \\
\hline
\end{tabular}

Table 5 shows the effect of pulp pH variation, for the values 9.7 and 10.8, on the flotation performance for the experiments using the 6 " and 4 " columns in rougher/cleaner configuration in experiments with Sample 1. The collector dosage was $130 \mathrm{~g} / \mathrm{t}$ and the depressant was $2900 \mathrm{~g} / \mathrm{t}$. It can be observed that a reduction of the pulp $\mathrm{pH}$ from 10.8 to 9.7 decreases the $\mathrm{P}_{2} \mathrm{O}_{5}$ content in the concentrate, going from $33.4 \%$ to $31.4 \%$. The reason for the dilution of the concentrate is exclusively caused by the increase of the $\mathrm{SiO}_{2}$ from $5.3 \%$ to values around $10 \%$, since the iron content is virtually the same. The increase in mass recovery, from $34.6 \%$ to $36.9 \%$ with the decrease of the $\mathrm{pH}$ value, is due the 
increase in the $\mathrm{SiO}_{2}$ content once the $\mathrm{P}_{2} \mathrm{O}_{5}$ recovery is almost the same for both $\mathrm{pH}$ values evaluated, reaching $72 \%$.

Table 5. Effect of $\mathrm{pH}$ variation on the flotation performance for experiments at 6" and 4" column flotation. Rougher/cleaner. Feed solids rate: $45 \mathrm{~kg} / \mathrm{h}$. Flotation studies with sample 1.

\begin{tabular}{ccccccccc}
\hline \multirow{2}{*}{ Test } & \multicolumn{2}{c}{ Recovery $(\mathbf{\%})$} & \multicolumn{3}{c}{ Grade (\%) } & \multicolumn{3}{c}{ Consumption $(\mathrm{g} / \mathrm{t})$} \\
\cline { 2 - 8 } & Mass & $\mathbf{P}_{\mathbf{2}} \mathbf{O}_{\mathbf{5}}$ & $\mathbf{P}_{\mathbf{2}} \mathbf{O}_{\mathbf{5}}$ & $\mathbf{F e}_{\mathbf{2}} \mathbf{O}_{\mathbf{3}}$ & $\mathbf{S i O}_{\mathbf{2}}$ & $\mathbf{p H}$ & Collector & Depressant \\
\hline 1 & 35.0 & 72.1 & 33.7 & 5.2 & 5.2 & & 132 & 3004 \\
2 & 33.5 & 70.2 & 33.5 & 5.6 & 5.2 & 10.8 & 127 & 2905 \\
3 & 35.3 & 73.8 & 33.1 & 5.9 & 5.5 & & 129 & 2947 \\
Average & 34.6 & 72.0 & 33.4 & 5.6 & 5.3 & & 129 & 2952 \\
\hline 1 & 33.5 & 68.2 & 31.7 & 5.2 & 9.1 & & 123 & 2815 \\
2 & 37.9 & 72.6 & 31.6 & 4.9 & 9.7 & & 125 & 2844 \\
3 & 36.2 & 69.7 & 31.3 & 5.1 & 9.8 & 9.7 & 133 & 3029 \\
4 & 39.9 & 74.9 & 31.0 & 5.2 & 10.2 & & 130 & 2959 \\
Average & 36.9 & 71.3 & 31.4 & 5.1 & 9.7 & & 127 & 2911 \\
\hline
\end{tabular}

Flotation results for Sample 2 in the experiments carried, out with the 6" and 4" columns, are shown in Table 6. The average collector dosage for the four tests was around $80 \mathrm{~g} / \mathrm{t}$ and the depressant was $2600 \mathrm{~g} / \mathrm{t}$ at the pulp $\mathrm{pH}$ of 9.7. The average mass and $\mathrm{P}_{2} \mathrm{O}_{5}$ recovery were $27 \%$ and $51 \%$ for a $\mathrm{P}_{2} \mathrm{O}_{5}$ grade of $32.8 \%$. Compared to the results obtained from Sample 1, the $\mathrm{SiO}_{2}$ content in the final concentrate was much lower in the experiments with Sample 2, reaching an average grade of $1.0 \%$. On the other hand, the iron content is very similar for both samples. The lower $\mathrm{SiO}_{2} \mathrm{content}_{\text {reached in }}$ the concentrate of Sample 2 can be explained by the lower grade in the slime feed sample that was analyzed at $12.5 \%$, compared with the $19.7 \%$ of Sample 1.

Table 6. Summary of the best results obtained in experiments at 6" and 4" column flotation. Rougher/cleaner. Feed solids rate: $45 \mathrm{~kg} / \mathrm{h} . \mathrm{pH}=9.7$. Flotation studies with Sample 2.

\begin{tabular}{cccccccc}
\hline \multirow{2}{*}{ Test } & \multicolumn{2}{c}{ Recovery (\%) } & \multicolumn{3}{c}{ Grade (\%) } & \multicolumn{2}{c}{ Consumption $\mathbf{( g / t )}$} \\
\cline { 2 - 7 } & Mass & $\mathbf{P}_{\mathbf{2}} \mathbf{O}_{\mathbf{5}}$ & $\mathbf{P}_{\mathbf{2}} \mathbf{O}_{\mathbf{5}}$ & $\mathbf{F e}_{\mathbf{2}} \mathbf{O}_{\mathbf{3}}$ & $\mathbf{S i O}_{\mathbf{2}}$ & Collector & Depressant \\
\hline 1 & 25.6 & 47.2 & 32.8 & 4.8 & 0.7 & 72 & 3000 \\
2 & 24.6 & 44.6 & 32.7 & 3.8 & 0.6 & 69 & 2880 \\
3 & 27.4 & 54.5 & 33.1 & 4.2 & 1.2 & 94 & 2380 \\
4 & 30.7 & 57.7 & 32.7 & 4.4 & 1.5 & 87 & 2215 \\
Average & 27.1 & 51.0 & 32.8 & 4.3 & 1.0 & 80 & 2618 \\
\hline
\end{tabular}

Regarding the reagent consumption (collector and depressant), it was observed that the average collector dosage is similar to the levels applied at the industrial scale in Brazilian plants. On the other hand, the depressant dosage is much higher, reaching values up to $2500 \mathrm{~g} / \mathrm{t}$. Usually, the depressant dosage does not exceed 1200-1300 g/t. Matiolo et al [15] evaluated the depressant dosage on apatite flotation from slimes. The results indicated that both parameters $\left(\mathrm{P}_{2} \mathrm{O}_{5}\right.$ grade and recovery) improve when the depressant dosage increases from $1230 \mathrm{~g} / \mathrm{t}$ to values reaching higher than $1700 \mathrm{~g} / \mathrm{t}$. It was also found that to control the iron impurities in the final flotation concentrate, the depressant dosage must be up $2200 \mathrm{~g} / \mathrm{t}$ to a maximum of $3000 \mathrm{~g} / \mathrm{t}$.

A similar approach to that evaluated in this study of recovering the valuable fine phosphate particles $(<45 \mu \mathrm{m})$ from their slimes through the application of the column flotation technique was tested by Abdel-Khalek [20]. Tests were performed using oleic acid as a collector for the phosphate minerals and sodium silicate as a depressant for their associated gangues. The main operating parameters affecting the performance of column flotation were investigated. The results indicate that the best operating conditions for column flotation of phosphate slimes are as follows: A superficial 
gas velocity of $0.84 \mathrm{~cm} / \mathrm{s}$, a frother concentration of $0.1 \mathrm{~kg} / \mathrm{ton}$, a column height of $230.5 \mathrm{~cm}$, and a superficial water velocity of $2.2 \mathrm{~cm} / \mathrm{s}$. Under these conditions, a product assaying $25.3 \% \mathrm{P}_{2} \mathrm{O}_{5}$ and $14.64 \%$ I.R. (insoluble residue), with a $\mathrm{P}_{2} \mathrm{O}_{5}$ recovery of about $51.52 \%$, is obtained from a feed containing $18.26 \% \mathrm{P}_{2} \mathrm{O}_{5}$ and $24.03 \%$ I.R. Such grades and recoveries are not obtained by applying the conventional froth flotation technique, even after cleaning the rougher concentrate. Recovery of more than $50 \%$ of phosphate from disposed slimes will improve the economic viability of the beneficiation process for phosphate ores. It will also help to solve the environmental problems associated with the disposal of these slimes.

\section{Conclusions}

It was possible to obtain apatite concentrates from two different slime samples with $\mathrm{P}_{2} \mathrm{O}_{5}$ grades higher than 33\%, which can be applied to SSP (single superphosphate) and TSP (triple superphosphate) production. Considering desliming and flotation, the overall mass recovery ranged from $9 \%$ to $12 \%$ and $\mathrm{P}_{2} \mathrm{O}_{5}$ recovery ranged between $29-42 \%$. It is estimated that the earnings obtained by recovery of the apatite from slimes may represent an increase in $4 \%$ of the overall $\mathrm{P}_{2} \mathrm{O}_{5}$ recovery at industrial plants. The results obtained in this study indicate that the flotation results were better in the circuits with higher column flotation (6" and 4"). The results can be explained by the application of a cavitation tube in the rougher stage in the 6" column. The improved flotation performance can be attributed to increased probabilities of collision and attachment and the reduced probability of detachment by the small size bubbles generated by the cavitation tube in comparison to the bubbles produced by the porous tube of the 4 " column flotation.

Author Contributions: Conceptualization, E.M., H.J.B.C and M.F.d.L.T; methodology, E.M., H.J.B.C and M.F.d.L.T.; formal analysis, E.M., H.J.B.C., M.F.d.L.T., R.N.d.A and A.S.d.F; investigation, E.M., H.J.B.C., M.F.d.L.T., R.N.d.A and A.S.d.F; resources, E.M., H.J.B.C. and M.F.d.L.T; data curation, E.M., H.J.B.C., M.F.d.L.T., R.N.d.A and A.S.d.F; writing-original draft preparation, E.M., H.J.B.C. and A.S.d.F; writing-review and editing, E.M., H.J.B.C., M.F.d.L.T., R.N.d.A and A.S.d.F; visualization, E.M., H.J.B.C., M.F.d.L.T., R.N.d.A and A.S.d.F; supervision, E.M., H.J.B.C., and M.F.d.L.T.; project administration, E.M., and M.F.d.L.T.,; funding acquisition, E.M., and M.F.d.L.T.

Funding: This research received no external funding.

Acknowledgments: The authors would like to thank the Brazilian Institutes supporting this research, namely $\mathrm{CNPq}$ for the scholarship to Amanda and Renata, and CETEM/MCTIC for the infrastructure. A special thanks to Copebras (CMOC International) for the financial support and permission to publish this work, and to process technician, Fabio Novaes, for his support during the experimental work.

Conflicts of Interest: The authors declare no conflict of interest.

\section{References}

1. Houot, R. Beneficiation of phosphatic ores through flotation: Review of industrial applications and potential developments. Int. J. Miner. Process. 1982, 9, 353-384. [CrossRef]

2. Dong, X.; Liu, S.; Yao, Y.; Liu, H.; Pei, Y. A review of new technological progress for benefication of refractory phosphate ore in China. IOP Conf. Ser.: Earth Environ. Sci. 2017, 63, 1-6.

3. Pourkarimi, Z.; Rezai, B.; Noaparast, M. Nanobubbles effect on the mechanical flotation of phosphate ore fine particles. Physicochem. Probl. Miner. Process. 2018, 54, 278-292.

4. Huynh, L.; Feiler, A.; Michelmore, A.; Ralston, J.; Jenkins, P. Control of slime coatings by the use of anionic phosphates: A fundamental study. Min. Eng. 2000, 13, 1050-1069. [CrossRef]

5. Ahmed, H.A.M. Optimization of desliming prior to phosphate ore upgrading flotation. Phys. Probl. Min. Proc. 2007, 41, 79-88.

6. Teague, A.J.; Lollback, M.C. The beneficiation of ultrafine phosphate. Min. Eng. 2012, 27-28, 52-59. [CrossRef]

7. Al-Thyabat, S. Evaluation of mechanical flotation of non-slimed Jordanian siliceous phosphate. Arab. J. Sci. Eng. 2012, 31, 877-887. [CrossRef]

8. Zhang, P.; Bogan, M. Recovery of phosphate from Florida beneficiation slimes I. Re-identifying the problem. Min. Eng. 1995, 8, 523-534. [CrossRef] 
9. Pradip, R.S.; Sankar, T.A.P. Selective flotation of Maton (India) phosphate ore slimes with particular reference to the effects of particle size. Internet J. Min. Proc. 1992, 36, 283-293.

10. Al-Thyabat, S.; Yoon, R.H.; Shin, D. Floatability of fine phosphate in a batch column flotation cell. Min. Metal. Proc. 2011, 28, 1110-1116. [CrossRef]

11. Liu, X.; Zhang, Y.; Liu, T.; Cai, Z.; Sun, K. Characterization and separation studies of fine sedimentary phosphate ore slime. Minerals 2017, 7, 94. [CrossRef]

12. Guimarães, R.C.; Peres, A.E.C. Industrial practice of phosphate ore flotation at Serrana-Araxá, Brazil. In Proceedings of the XXI International Mineral Processing Congress, Rome, Italy, 23-27 July 2000; B9-17.

13. Guimarães, R.C.; Peres, A.E.C. Experiência brasileira de produção de concentrado fosfático a partir de lamas. In Proceedings of the XIX Encontro Nacional de Tratamento de Minérios e Metalurgia Extrativa, Recife, Brasil, 26-29 November 2002; Volume I, pp. 247-253. (In Portuguese).

14. Guimarães, R.C.; Peres, A.E.C. Production of phosphate concentrates from slimes: Brazilian experience. In Proceedings of the XXII International Mineral Processing Congress, Cape-Town, South Africa, 29 September-3 October 2003; pp. 606-612.

15. Matiolo, E.; Couto, H.J.B.; Teixeira, M.F.L.; Freitas, A.S.; Almeida, R.N. Recovery of apatite from slimes of a Brazilian phosphate ore. J. Wuhan Inst. Technol. 2017, 39, 39-48.

16. Ipek, H.; Ozdag, H. An investigation into the enrichment of phosphate slime by column flotation. Dev. Miner. Process. 2000, 13, C8a-1-C8a-5.

17. Tao, Y.; Liu, J.; Yu, S.; Tao, D. Picobubble enhanced fine coal. Sep. Sci. Technol. 2006, 41, 3597-3607. [CrossRef]

18. Zhou, Z.A.; Xu, Z.; Fich, J.A.; Hu, H.; Rao, S.R. Role of hydrodynamic cavitation in fine particle flotation. Int. J. Miner. Process. 1997, 51, 139-149. [CrossRef]

19. Zhou, Z.A.; Xu, Z.; Finch, J.A.; Masliyah, J.H.; Chow, R.S. On the role of cavitation in particle collection in flotation-A critical review. II. Min. Eng. 2009, 22, 419-433. [CrossRef]

20. Abdel-Khalek, N.A.; Hassan, F.; Arafa, M.A. Separation of valuable fine phosphate particles from their slimes by column flotation. Sep. Sci. Tech. 2000, 35, 1077-1086. [CrossRef]

(C) 2019 by the authors. Licensee MDPI, Basel, Switzerland. This article is an open access article distributed under the terms and conditions of the Creative Commons Attribution (CC BY) license (http://creativecommons.org/licenses/by/4.0/). 